\title{
THE PRINCIPLE OF GOOD FAITH IN PUBLIC INTERNATIONAL LAW
}

\author{
El principio de buena fe en el Derecho internacional público
}

\author{
Talya Uçaryilmaz \\ Oxford Institute of European and Comparative Law \\ Bilkent University Faculty of Law \\ http://dx.doi.org/10.18543/ed-68(1)-2020pp43-59
}

Recibido: 23.10 .2019

Aceptado: 29.12.2019

\begin{abstract}
Honesty, loyalty and reasonableness together refer to the principle of good faith in contemporary private law. The principle of good faith historically emerged as a natural law principle deriving from Roman law of nations, the universal set of rules applicable for all mankind. However, it also has immense historical effects on the early modern theories of international law. Being based on natural law and morality, good faith is well-equipped to be a fundamental standard of behavior in contemporary international law concerns. Good faith manifests itself as pacta sunt servanda as the basis of international treaty law. As a principle referring to honesty, loyalty and reasonableness, it guarantees the prohibition of the abuse of power and provides equitable solutions in legal relationships between sovereigns and private actors. Accordingly this article examines the application of the classical Roman principle of good faith in international law from a transhistorical perspective to clarify its contemporary applications, taking refugee law as an example. It concerns itself with the fundamental elements of good faith, the historical emergence of the principle, its relationship with early modern international legal theories and its contemporary significance in refugee law.
\end{abstract}

\section{Key Words}

Good Faith, Grotius, International Law, Pacta Sunt Servanda,, Refugee Law. 


\section{Resumen}

La honestidad, la lealtad y la razonabilidad juntas se refieren al principio de buena fe en el Derecho privado contemporáneo. El principio de buena fe surgió históricamente como un principio de derecho natural derivado del Derecho romano de las naciones, el conjunto universal de reglas aplicables a toda la humanidad. Sin embargo, también tiene inmensos efectos históricos en las primeras teorías modernas del Derecho internacional. Al estar basada en la ley natural y la moral, la buena fe está bien equipada para ser un estándar de comportamiento fundamental en las preocupaciones del derecho internacional contemporáneo. La buena fe se manifiesta como pacta sunt servanda como la base del derecho internacional de los tratados. Como principio que se refiere a la honestidad, la lealtad y la razonabilidad, garantiza la prohibición del abuso de poder y brinda soluciones equitativas en las relaciones legales entre los soberanos y los actores privados. En consecuencia, este artículo examina la aplicación del principio clásico romano de buena fe en el Derecho internacional desde una perspectiva transhistórica para aclarar sus aplicaciones contemporáneas, tomando como ejemplo el Derecho de los refugiados. Se ocupa de los elementos fundamentales de la buena fe, el surgimiento histórico del principio, su relación con las primeras teorías jurídicas internacionales modernas y su importancia contemporánea en el Derecho de los refugiados.

\section{Palabras clave}

Buena fe, Grocio, Derecho internacional, pacta sunt servanda, Derecho de los refugiados. 
Sumario: I. InTroduction. II. The EFFect of Roman LaW IN INternational Law. III. Good Faith as a Natural Law Principle. IV. The Place of Good Faith in Contemporary International LAw. 1. General Overview. 2. International Treaties and Pacta Sunt Servanda. 3. The Principle of Good Faith in Refugee Law. V. CoNCLUSION. BIBLIOGRAPHY.

\section{INTRODUCTION}

Good faith is one of the fundamental legal principles, imposing a moral behavioural standard of honesty, loyalty and reasonableness to different actors in social relationships. Before gaining its legal character in classical Roman law, bona fides or good faith had been understood as one's commitment to his/her own words, fidelity and honesty while symbolizing tacitum in pectore numen: The virtue of loyalty existing in the internal world of the human beings. Being a universal moral value that turned into a binding legal principle, it carries a transnational significance and facilitates sailing the legal world. The principle of bona fides, is applicable in different jurisdictions and different legal realms. Such universality makes it a bridge between different legal traditions, unifiying them, and emphasizing the similarities.

The principle of good faith in its objective sense is mainly used in contract law to provide the necessary elasticity as an antidote to rigidity of law. However, this principle is also the basis of early-modern international law theories. The place of Roman law in the development of the international law theories is based on natural law, ius gentium and the concept of good faith as their product. The contemporary significance of the good faith principle in international law especially manifests itself in international treaty law with the cloak of pacta sunt servanda. However in many concrete cases, one can examine the importance and applicability of the good faith principle in international legal scene.

This article aims to evaluate the historical process of adopting such a moral value as the fundamentals of contemporary international law and to apply the universal criteria of good faith to one of the major contemporary problems: The legal regime of refugees and asylum seekers. It is constructed as a transhistorical analysis of the good faith principle from Roman law to early modern political-legal theory, in order to set the necessary basis for contemporary concerns.

\section{THE EFFECT OF ROMAN LAW IN INTERNATIONAL LAW}

Roman law has always been considered as the history of private law in Continental Europe. However, on the opposite of the general belief, it does 
not only have immense historical and progressional effects on modern civil law but also on international law. There are several reasons why Roman private law constituted the basis of early modern international law theories. First, Roman characteristics have always been the model for the civic values of the modern states. ${ }^{1}$ Second, the relationships between sovereigns and private actors were seen as morally equal, and third, Roman ius gentium is the fundamentals of modern law of nations.

One of the civic values of modern states is undoubtedly the principle of bona fides or good faith, that is prima facie a Roman civil law principle. However, the principle of good faith influenced international law in several dimensions, mainly international treaty law, being an intrinsic value incorporated to international agreements. Good faith simply refers to honesty, loyalty and reasonableness in social and legal relationships. In the realm of international law, it requires to adopt a standard of behaviour, stressing fidelity to treaties, proportionality and prohibition of the abuse of power for different actors.

Grotius took Roman bona fides, Cicero's writings and Ulpian's digest as a basis of his theory of law of nations. Main reason why Grotius took Roman law as a starting point, was his belief that the Roman culture valued fides more than others. In other words, Roman conception of bona fides was also one of the factors that shaped the future of international law. The principle of good faith, has been most systematically focused in De Iure Belli Ac Pacis. According to the jurist, not honoring a promise is the lowest stage of human dignity, since both public and private fides is the pre-condition of all sorts of human interactions. He, therefore equalized the concepts of honesty, loyalty, equity and bona fides, just as in the works of the post-glossators of medieval era, later adopted by contemporary contract law. ${ }^{2}$ Although Grotius was focused on natural law, it was accepted as a valid statement of positive international law even of his time, and the postulate underlying his work was good faith. ${ }^{3}$

Second, Roman private law principles were directly incorporated to international law theories because Grotius considered states as private actors.

${ }^{1}$ Richard Tuck, The Rights of War and Peace (New York: Oxford University Press, 1999), 24.

${ }_{2}$ Manfred Wolf and Jörg Neuner, Allgemeiner Teil des Bürgerlichen Rechts (München: C.H. Beck, 10. Auflage, 2012), 232, Max Kaser, Rolf Knütel and Sebastian Lohsse, Römisches Privatrecht (München: C. H. Beck, 21. Auflage, 2019), 223, Giovanni Pugliese, Istituzioni Di Diritto Romano (Torino: Giappichelli, 2. Edizione, 1992), 265, René Robaye, Le Droit Romain (Louvain-la-Neuve: Academia-Bruylant, 5. Édition, 2016), 209.

3 Haim Cohn, « The Grotian Concept of Good Faith », Tel Aviv University Studies in Law 7 (1985-1986), 9-19, 10. 
Before Grotius, Gentili also regarded law of nations as a form of private law comprised of common rules for the people of different nations. ${ }^{4}$ According to this idea, the rule, which governs a private citizen in his /her own state, should also govern a sovereign in the universal state formed by the world. The natural law principle of good faith plays a major role in the development of the international law theory because the relationship between individuals and between sovereign states has no significant moral difference, hence are governed by similar principles. ${ }^{5}$ Nations and their rulers should be seen as the individuals in terms of Roman principles of private law, who have to act in accordance with the principle of good faith. ${ }^{6}$ This view is also compatible with Kelsenian international law theory, taking international law in the framework of general theory of law and suggesting domestic law and international law are not intrinsically different.?

Classical Roman law, however, did not contain any special passages related to international law. It was the $11^{\text {th }}$ century scholars who developed their international legal theories mostly based on classical private law texts. On the other hand, the relationship was bidirectional. Fides was also focused in public law, deriving from the word "foedus" which signified alliances between states in Roman international law. Good faith has always been central as a measurement of proportionality between obligations of the different sovereign parties. ${ }^{8}$

Third, the influence of Roman law in international law is the direct result of Roman ius gentium, as the major starting point existing in the doctrine. ${ }^{9}$ The term "ius gentium" originally referred to a special segment of municipal Roman law primarily for litigation among or with foreigners, applied by the praetor peregrinus. ${ }^{10}$ However in A.D. 212, as Emperor Caracalla issued the

${ }^{4}$ Merio Scattola, «Alberico Gentili » in The Oxford Handbook of the History of International Law, ed. Barno Fassbender and Anne Peters, (Oxford: Oxford University Press, 2012), 1092-1097, 1094.

5 Tuck, War and Peace..., 84.

${ }^{6}$ See Montesqieu, L'esprit des Lois, I.10.2., Tuck, War and Peace...,56.

7 Barno Fassbender, "Hans Kelsen » in The Oxford Handbook of the History of International Law, ed. Barno Fassbender and Anne Peters (Oxford: Oxford University Press, 2012),1167-1172, 1171.

8 Arthur Nussbaum, « The Significance of Roman Law in the History of International Law », University of Pennsylvania Law Review 100, n. ${ }^{\circ} 105$ (1952), 678-687, 679.

9 Kaius Tuori « The Reception of Ancient Legal Thought in Early Modern International Law Histories» in The Oxford Handbook of the History of International Law, ed. Barno Fassbender and Anne Peters, (Oxford: Oxford University Press, 2012), 1012-1033, 1015.

${ }^{10}$ D.1.2.2.28, Paul Jörs, Wolfgang Kunkel and Leopold Wenger, Römisches Recht, (Heidelberg: Springer, 3. Auflage, 1949), 58, Kaser, Knütel and Lohsse, Römisches Privatrecht, 36. 
famous Constitutio Antoniana that dictated the rules of ius gentium to be also applicable to the civilians, the rules of ius civile and ius gentium had merged. ${ }^{11}$ At the same time, because of the effect of Greek natural philosophy, ius gentium started to comprise universal rules deriving from mores civitatis, natural reason (ratio naturalis) and fundamental values of humankind. As a body of rules applicable to the conflicts with foreign elements, ius gentium was the universal set of rules of the "civilized" humanity, mainly consisted of the rules of ius naturale and common sense. ${ }^{12}$

Grotius considered ius gentium as a tacit agreement by the greater part of the members of the international community to rationalize the expansion on the Indies. However, the Grotian ideas that ius gentium derives from the natural law, and it is a posteriori determined by the consensus gentium, are the basis of modern international relations theories. ${ }^{13}$ Similarly, Vitoria, described ius gentium as a set of legal rules between natural law and positive law, taking its validity not from the municipal law but from the reason of all peoples. ${ }^{14}$ Roman ius gentium, as a quasi-cosmopolitan legal system based on natural law, is an indication that Roman law was not traditionalist and conservative, but open to any changes since it set out universal legal principles derived from natural reason.

The view that ius gentium is not only the international private law of Romans but also a cosmopolitan law in Kantian sense was strongly adopted by Suarez and Wolff. Ius gentium was understood as a quasi-political moral unity of the human race, as a result of agreement. ${ }^{15}$ Wolff took the position that state of nature is sociable in character. Nature herself established society, and binds men and all nations as ius gentium. ${ }^{16}$ In Wolff's view, ius gentium could be voluntary in form of a universal consensus, stipulative deriving from pacts among nations, and customary as the result of the will of nations. ${ }^{17}$ The voluntary and customary ius gentium together created the principle of good faith. Kant, as a heir of Grotius and Wolff, believed that aggressive and

${ }^{11}$ Herbert Hausmaninger and Walter Selb, Römisches Privatrecht (Wien: Böhlau, 9. Auflage, 2001), 47, Alberto Burdese, Manuale di Diritto Privato Romano, (Torino: UTET, 1969), 26, Michel Villey, Le Droit Romain (Paris: Puf, 2012), 65.

12 Nussbaum, Roman Law.., 682, Martti Koskenniemi, « History of International Law Histories » in The Oxford Handbook of the History of International Law, ed. Barno Fassbender and Anne Peters, (Oxford: Oxford University Press, 2012), 943-971, 944.

13 Koskenniemi, History..., 947-948.

14 Tuori, Ancient Legal Thought, 1019-1020.

15 See De legibus, II, XIX, 9, III, II, 6.

16 Tuck, War and Peace..., 187.

17 Emanuelle Jouannet, « Emer de Vattel » in The Oxford Handbook of the History of International Law, ed. Barno Fassbender and Anne Peters, (Oxford: Oxford University Press, 2012), 1118-1121, 1119. 
interventionary foreign policy was immoral, hence good faith as a moral concept should play an important role in ius gentium..$^{18}$ This was the reflection of an unsocial sociability, that is antagonism in the society that caused a law governed social order and created the need to moral principles like good faith both in civil and international law. ${ }^{19}$ These three reasons discussed above, are interrelated and cluster around the principle of good faith. As a necessary social and modern civic value coming from the private law tradition, good faith flourished within Roman ius gentium, custom and aequitas..$^{20}$

\section{III.GOOD FAITH AS A NATURAL LAW PRINCIPLE}

The root of the principle of good faith is the notion of fides, that emphasized the virtue of fidelity in earlier times. Fides started to comprise the honest behaviour of a person in a social relationships and later adopted a legal meaning as honoring the promise, adequate performance of the consensual obligations and protection of reliance. ${ }^{21}$ In the classical period, the principle of bona fides had both a subjective and objective meaning, since the term fides not only meant faith and protection of reliance in an objective sense but also the intent of the subjective actors in contractual life..$^{22}$ Good faith in its objective sense, requires the subjects of a legal system to adopt a loyal and honest behavioural standard while exercising their rights and performing their obligations, aiming to protect the reasonable reliance and other parties' interest that are worth being protected. ${ }^{23}$

Scaevola considered bona fides as summa vis (the greatest power) just like Cicero who referred to it as the fundamentum iustitiae (fundamentals of

18 Tuck, War and Peace..., 165.

19 Tuck, War and Peace..., 18.

${ }^{20}$ Arnulf Becker Lorca, " Eurocentrism in the History of International Law » in The Oxford Handbook of the History of International Law, ed. Barno Fassbender and Anne Peters (Oxford: Oxford University Press, 2012), 1034-1057, 1043.

${ }_{21}$ Theodor Mommsen, Römische Geschichte, 1. Band, (Berlin: Weidmannsche, 2. Auflage, 1856), 153, 209, Gérard Freyburger, Fides, Étude Sémantique et Religieuse Depuis les Origines jusquà̀ l>Époque Augustéenne, (Paris: Les Belles Lettres, Collection d)Etudes Anciennes. Antiquité Latine, No: 35, 1986), 99.

22 Filippo Gallo, « Bona Fides E Ius Gentium », in Il Ruolo della Buona Fede Oggettiva nell Esperienza Giuridica Storica e Contemporanea atti del Convegno Internazionale di Studi in Onore di Alberto Burdese, ed. Alberto Burdese, Luigi Garofalo (Padova: CEDAM, 2003), 115-153, 132.

${ }^{23}$ Bettina Hürlimann-Kaup and Jörg Schmid, Einleitungsartikel des ZGB und Personenrecht, (Basel: Schultess, 2. Auflage, 2010), 70, Simon Whittaker and Reinhard Zimmermann, " Good Faith in European Contract Law: Surveying the Legal Landscape » in Good Faith in European Contract Law, ed. Simon Whittaker and Reinhard Zimmermann (Cambridge: Cambridge University Press, 2000), 7-63, p. 30. 
justice).$^{24}$ The obligation of behaviour that the good faith rule dictates, is bene agere which is acting as "bonus vir" or a reasonable honest man in social relations. ${ }^{25}$ It is accepted in contemporary civil law that, bona fides is a natural law principle that contains a mandatory moral standard. ${ }^{26}$ However since it is a concept that is sufficiently ambigous to be applied not only in civil law but also in international law, certain criteria must be specified. Historically, the criteria are determined in the light of the studies of post-glossator jurists which were also the starting point of the lawyers such as Grotius and Vasquez that theorized the idea of international law. The fundamental elements of bona fides are honesty, loyalty and reasonableness.

The criteria of loyalty is simply the performance of the consensual obligations and being faithful to promises while honesty as an objectified value, requires the disclosure of the necessary information that can harm the other party in case they are unknown. It also refers to taking the reasonable and legitimate interests of the other actors into consideration. Reasonableness on the other hand, indicates expediency of the behaviour and constists some sub-criteria such as avoiding contradictory conducts, acting in consistency with the reasonable expectations of the other party and avoiding creating excessive imbalance between party interests..$^{27}$ In other words, reasonableness criterion of good faith reflects the principle of proportionality in international law.

The reason why good faith is and should be the basis of international legal relations is its essence in natural law. The natural law principle of bona fides has always had two requirements: The absence of dolus (deceit) and the obligation to behave according to aequitas naturalis (natural equity). Accordingly, the principle of good faith started to create implied obligations deriving from the laws of nature amongst parties, as such they are not even required to be agreed in the contract. The obligation-creating function of good faith is the basis of pacta sunt servanda and proportionality in international law. In De Iure Praedae, Grotius demonstrated that good faith is a veritable necessity in contacts with foreign nations in the outer parts of the world. In case there is no common religious bond or a bond based upon a covenant, two actors are linked to each other by natural ties based on good faith, benevolence and clemency. Such natural ties unite all human beings, states or all actors in a legal relationship equally. ${ }^{28}$

${ }^{24}$ See Cicero, De Officiis, 1. 23.

25 De Buján, Iudicia Bonae Fidei...,. 45.

26 Jean Domat, Les Loix Civiles dans Leurs Ordre Naturel, (Paris: 1703)

27 James Gordley, " Good Faith in Contract Law in Medieval Ius Commune » in Good Faith in European Contract Law, ed. Simon Whittaker and Reinhard Zimmermann (Cambridge: Cambridge University Press, 2000), 93-118.

${ }^{28}$ See Grotius, De Iure Praedae, 14. 
The idea of Clinias the Cretan, that is humanity is in a condition of public war of every man against every man in the state of nature, which was later adopted by Hobbes and Bacon, is not strange to the contemporary contract law in the neo-liberal paradigm. Today, the war -between individuals or sovereigns- is not physical but intellectual and financial, resources are limited and the main aim is to self-preserve. This reflects such idea that the principle of good faith regulates the conduct between rivals in contract law and sovereign powers in international law. ${ }^{29}$

In parallel, Grotius took Roman law as an alternative to develop a neutral natural law doctrine. ${ }^{30}$ The Grotian concept of natural law is a mixture of human nature and of ideal postulates of human morality, that implies desirable standards of human behaviour, for which fides becomes a criterion of civilization. ${ }^{31}$ Good faith deriving from natural human life is shaped around the idea of one's own good takes precedence over the good of another, as the maxim "I am my own closest neighbour" dictates. ${ }^{32}$ Roman good faith does not require a purely altruistic approach. It signifies honesty and loyalty between rivals. This approach, coherent with the works of Hobbes and Grotius, makes this principle compatible with contemporary international law. Such realism set the necessary basis for the principle of good faith to be applicable while providing a minimal ethical standard in international scene.

Good faith does not have to come within positive law, nor within generosity or compassion. It belongs in the moral category of conscientia that creates an innate sense of justice within the state of nature, thus is properly classified as natural law. ${ }^{33}$ In parallel, Rousseau defended that good faith comes from rerum natura but it is the idea of self-preservation that relies on such a fundamental moral agreement amongst men. ${ }^{34}$ Rousseau was agnostic about the distinction between altruism and selfishness, making the Roman understanding of the principle of good faith central to contemporary international law. The state of nature analogy for the international law is more than understandable, since there are no enforceable international legal rules to govern international relations. That is why, less reliance on positive law but more reliance on voluntary constraint or pacta sunt servanda was needed. ${ }^{35}$

\footnotetext{
${ }^{29}$ See Plutarchus, Paradoxorum Iuris Civilis Libros, VI, 2, 21.

${ }^{30}$ See Grotius, De Cive, XI, 4.

${ }^{31}$ Haim, Good Faith..., 12.

32 Tuck, War and Peace..., 86.

${ }^{33}$ Haim, Good Faith..., 13.

${ }^{34}$ Tuck, War and Peace..., 132, 189.

${ }^{35}$ Haim, Good Faith..., 10, George Cavallar, « Jean Jacques Rousseau » in The Oxford Handbook of the History of International Law, ed. Barno Fassbender and Anne Peters (Oxford: Oxford University Press, 2012), 1114-1117, 1115, Knud Haakonssen, « Samuel
} 


\section{IV.THE PLACE OF GOOD FAITH IN CONTEMPORARY INTERNATIONAL LAW}

\section{General Overview}

The significance of the principle of good faith is visible in major areas of international law if one looks carefully. In the nuclear test case of 1974, ICJ set that the governing principle of international law in terms of creation and performance of the international obligations, is good faith. ${ }^{36}$ As Grotius put, good faith, expressed or implied, is the foundation of every treaty between sovereigns. The idea of peace is not static, it is a condition of good faith between nations. Fidelity to treaties, good faith and mutual understanding coming from the Roman law are the condiciones sine quibus non of international law. ${ }^{37}$ As the Kantian approach suggests, the telos of law and history is the federation among nations and individuals. ${ }^{38}$ The reason why Grotius based his works on Roman law, is that Roman law consisted advanced contract law remedies in ius gentium like good faith and pacta sunt servanda. ${ }^{39}$

Historically, the most clear reflections of the good faith principle in international law have been existed in three major areas: International treaty law as the principle of pacta sunt servanda, treatment of envoys and determining the conditions of just war. In parallel, Grotius argued that good faith matters the most in the handling of treaties under the theory of pacta sunt servanda in terms of conclusion, performance and interpretation. ${ }^{40}$ While pacta sunt servanda clearly refers to the elements of honesty and loyalty of Roman good faith, treatment of envoys and determining the conditions of just war were reflections of reasonableness and proportionality.

These major areas are also intertwined. Pufendorf and Grotius argued that if someone intentionally failed to fulfill a legally binding pact, it constituted a casus belli, as the law of war was never separate from the law of treaties. ${ }^{41}$ Again, the legal regime of the envoys was constructed according to the rules concerning the employer's responsibility from the employee's actions,

Pufendorf» in The Oxford Handbook of the History of International Law, ed. Barno Fassbender and Anne Peters (Oxford: Oxford University Press, 2012), 1102-1105, 1103.

${ }_{36}$ Nuclear Tests Case (Australia v France) (Merits) [1974] ICJ Rep 253.

37 Walter Simons, The Evolution of International Public Law in Europe Since Grotius, (New Haven: Yale University Press, 1931), 23.

38 Koskenniemi, History...,. 944.

39 Tuori, Ancient Legal Thought...,1022.

${ }^{40}$ Other private law analogies are mainly about the freedom of the high seas, terra nullius and uti possidetis. See Grotius, De Fide e Perfidia, Chapter 6.

${ }^{41}$ Tuori, Ancient Legal Thought..., 1027, See Grotius, De Iure Belli Ac Pacis, III, 4, 19. 
referring to the private law principle of aequitas and utlitas..$^{42}$ Grotian concept of good faith is applicable in times of peace for mutual existence, and in times of war, since the actors in international area as natural or legal human beings should also act upon good faith towards each other.

\section{International Treaties and Pacta Sunt Servanda}

The principle of good faith is the basis of all social relationships and the criterion of civilization. As a human made artefact, it is also the basis of the concept of 'contract'. Good faith dominates the mutual relationships between different actors in pre-contractual, contractual, and post-contractual stages. It does not only function as a subsidiary principle that is applied as ultima solutio, but also constitutes the moral basis of keeping the promises. Good faith rule in international law has two correlative functions. First, it manifests itself as pacta sunt servanda, 'agreements must be kept', as a reflection of honesty and loyalty. Second, it operates as a rule of interpretation.

Pacta sunt servanda is known to be one of the oldest principles of international law. According to Art. 26 of the Vienna Convention on the Law of Treaties of 1969: "Every treaty in force is binding upon the parties to it and must be performed by them in good faith." In the absence of any supranational authority, states have nothing to rely upon for the due fulfilment of international obligations but their trust in the good faith of the other parties. As King John proclaimed in Magna Carta, "Both we and the barons have sworn that all this shall be observed in good faith and without deceit." In the Nuclear Tests Case, ICJ ruled that: "Just as the very rule of pacta sunt servanda in the law of treaties is based on good faith, so also is the binding character of an international obligation. Thus interested States may take cognisance of unilateral declarations and place confidence in them, and are entitled to require that the obligation thus created be respected.» ${ }^{43}$

Pacta sunt servanda refers to the binding nature of promises. It is a demonstration that good faith dominates the performance and interpretation of international treaties, being a fundamental legal principle derived from natural equity. The Kelsenian approach suggests that good faith is not a legal rule but a law of prudence. It does not have to be codified in positive law, since it is a natural law principle. It is also an underlying primordial law of human nature, ruling the conditions of people living together. According to this view, there must be a higher law behind a treaty to judge it. It is a law without the legislator and executor. It is also the law that makes sovereigns

\footnotetext{
${ }^{42}$ See Groitus, De Iure Belli Ac Pacis, III, 22.

${ }^{43}$ Nuclear Tests Case (Australia v France) (Merits) [1974] ICJ Rep 253.
} 
responsible. ${ }^{44}$ Contractual obligations should be honored, and the central component is the concept of good faith. ${ }^{45}$

In this regard, Art. 31 of the Vienna Convention focuses on the interpretative function of the good faith principle. In terms of ambiguity, Roman good faith requires the treaty to be interpreted according to proportionality and equity, rather than the literal meaning of the contract. ${ }^{46}$ From Roman private law to modern contract law, contra proferentem rule dictates the interpreation of the contracts to be made to the disadvantage of the party who stipulated the contractual provisions. In parallel, contra auctorem rule has been accepted since Grotius in international law, prevailing that every document is to be interpreted strictly in favour of the vanquished. ${ }^{47}$

UN Charter Article 2 stipulates that: "All Members, in order to ensure to all of them the rights and benefits resulting from membership, shall fulfill in good faith the obligations assumed by them in accordance with the present Charter." This article is one of the core provisions of international treaty law, since in Grotian sense good faith is not only the principle that hold all governments together, but is the keystone by which the larger society of nations is united. Destroy this, says Aristotle, and you destroy the intercourse of mankind. ${ }^{48}$

\section{The Principle of Good Faith in Refugee Law}

International law, as historically put, does not only regulate the relationships between sovereigns. Individuals and states may also have duties and responsibilities towards each other under international rules. The Kantian approach of cosmopolitan law being closely related to Roman ius gentium, regulates relationships between states and foreigners, refugees, traders, businesses or collective agents. The duty to act upon good faith also manifests itself in the legal regime of refugees or broadly, asylum seekers. ${ }^{49}$ The reason why refugee law is a good example for the significance of Roman bona fides is its requirement of a delicate balance of interests between asylum seekers and states, as well as a fragile measure of honesty and equity. This concrete example demonstrates that good faith in international law, coming from

${ }^{44}$ Simons, Public Law..., 73, 75.

45 Talya Uçaryılmaz, Bona Fides, (Ankara: Yetkin Yayınevi, 2018) Tuori, Ancient Legal Thought...,1027.

${ }_{46}$ Grotius, De Iure Belli Ac Pacis, II, 16.

${ }^{47}$ Hail, Good Faith..., 17.

48 Grotius, De Iure Belli Ac Pacis, III, 25.

49 As in the 1951 Refugee Convention the definition of the concept of refugee is narrow, in this article the term asylum seekers is used as an umbrella category. 
Roman law, is not only truthfulness but also reasonableness. Roman legacy requires each contemporary case to be evaluated by its own merit.

It is unclear, whether there is a positive law requirement of objective good faith in refugee law. The 1951 Convention Related to the Status of Refugees Art. 2 provides that, "Every refugee has duties to the country in which he finds himself, which require in particular that he conform to its laws and regulations as well as to measures taken for the maintenance of public order." The 1951 Convention is not self-applying and the states are obliged to incorporate the basic universal principles that they have accepted in international law to their domestic laws. The provisions are considered together with the 1969 Vienna Convention. As such, it is interpreted as the requirement to provide necessary protection to refugees, by assuring their fundamental rights and freedoms. ${ }^{50}$ Due to the fundamental obligation of bona fides and Vienna Convention as its positive law appearance, every state has the obligation to implement international obligations in good faith that also entails taking the necessary measures to prevent discrimination and setting up the necessary mechanisms for the well-being of asylum seekers. ${ }^{51}$ However, Roman ius gentium and theory of cosmopolitan law requires the obligations to be bilateral.

That is to say, everyone, in the territory of another state, is subject to its jurisdiction and bound by national laws and that not all the obligations lie with the state, as the asylum seekers have the obligation to cooperate. ${ }^{52}$ The legally non-binding refugees handbook issued by UNHCR, stipulates that the applicant should tell the truth and assist the examiner to the full in establishing the facts of his/her case and supply all pertinent information concerning himself/herself and the past experience in as much detail. ${ }^{53}$ This provision clearly reflects the honesty element of Roman bona fides. Here, the principle of good faith is described as a moral rule of a general nature, not punitive in character..$^{54}$

One can argue that, there is no positive requirement of good faith for the asylum seekers in international law, if not in domestic law. However, as the principle of good faith is one of the fundamental principles of law, it would

${ }^{50}$ Guy Goodwin-Gill, « Article 31 of the 1951 Convention relating to the Status of Refugees: Non-penalization, Detention and Protection » UNHCR Department of International Protection Papers, (2011), 3.

${ }^{51}$ Guy Goodwin-Gill, «The International Law of Refugee Protection » in The Oxford Handbook of Refugee and Forced Migration Studies, ed. Elena Fiddian-Qasmiyeh, Gil Loescher, Katy Long, Nando Sigona, (Oxford: Oxford University Press, 2014), 36-48, 40.

52 Ryszard Piotrowicz, « Asylum Seekers, Good Faith and the State » International Joumal on Minority and Group Rights 20, (2013), 263-278, 268.

${ }_{53} \mathrm{http} / /$ www.unhcr.org/publications/legal/3d58e13b4/handbook-procedures-criteria-determining-refugee-status-under-1951-convention.html (22.10.2019)

${ }^{54}$ Piotrowicz, Asylum Seekers..., 276, 271. 
be very difficult in practice to categorically reject it. International jurisprudence also shows that the obligation of good faith and co-operation for asylum seekers exists. Nonetheless, the obligation to be truthful is also evaluated according to the additional criteria of good faith, mainly loyalty and reasonableness. The principle of good faith does not only refer to the honesty in fact but rather requires equitably expectable honesty of the parties. In some cases, failure to tell the truth does not entitle a state automatically to reject a person>s application, as the states remain bound by the principle of non-refoulement. Not being entirely truthful about one's circumstances does not alter the fact that he/she may have a legitimate claim to international protection. ${ }^{55}$

In some cases, the observation of the principle of pacta sunt servanda by the states and the obligation of honesty for the asylum seekers may conflict. The solution is to solve each case according to equity and reasonableness, or in other words according to the wider understanding of the Roman good faith principle. Such good faith obligation exists mutually. In one hand, the situation and truthfulness of the asylum seekers must be determined according to their own circumstances, equity and reasonableness. In the other hand, states have a right to a fair and efficient asylum procedure. States are not obliged to give the benefit of every doubt to all the applications of asylum seekers. ${ }^{56}$ Nonetheless, all the actors in international scene have the obligation to act honestly, loyally, and reasonably.

The unity of law is based on ethical principles, and to avoid a utopian moralism, one has to apply realist ethics as a perspective for legal analysis. Ius gentium and natural law on the other hand, create a horizon of modernity and progress. ${ }^{57}$ Good faith rule determines the legal effects of the subjects' declarations and behaviour and the extent of their duties as a moral principle..$^{58}$ Bona fides requires the expectations of mutual conformity to be agreed or implied standards to be duly and unfailingly fulfilled, hence is an essential element for the interactions between private actors, states and states v. individuals..$^{59}$ It is understandable that the concept of good faith is found highly abstract. However, with such abstractness, good faith determines the measure of the acceptable that must not be exceeded. The Roman private law principle of good faith is still the oil in the machine of international law.

${ }^{55}$ Guy Goodwin-Gill, « Damian v. Secretary of State for the Home Department Comment: Refugee Status and Good Faith » International Journal of Refugee Law 12, n. ${ }^{\circ}$, (2000), 663-671.

${ }_{56}$ Piotrowicz, Asylum Seekers..., 268

${ }^{57}$ Koskenniemi, History..., 970.

58 Michel Virally, " Good Faith in Public International Law » The American Journal of International Law, 77, n. ${ }^{\circ}$ 1, (1983), 130-134, 133.

${ }^{59}$ Haim, Good Faith..., 10. 


\section{CONCLUSION}

The principle of good faith operates as a bridge between different legal systems because of its amorphous nature and its basis in universal moral-ethical values deriving from Roman private law. Fides, one of the strictly adopted moral values in the Roman civilization, gained a legal character with the applications of Roman private law, transforming it into the concept of bona fides. Roman bona fides being a moral value based on natural law, constituted the roots of early modern international law theories.

The question why one principle set the whole basis of international law has several answers. It is argued that the importance of good faith in international scene lies on its relationship with natural law and its genealogy from Roman ius gentium as a form of cosmopolitan law. The principle of good faith signifies honesty, loyalty and reasonableness between rivals in contract law and sovereigns in international law. Such realistic approach makes good faith central for contemporary international law, while setting the necessary behavioural standard for respecting human rights and fundamental values.

The contemporary significance of good faith in international law can be best observed in international treaty law. Roman bona fides is the origin of the international law principle pacta sunt servanda, existing in the soul of every international treaty by nature. However, coming from the Roman ius gentium, the principle is also applicable to the relationships between sovereigns and other private actors such as collective agents, refugees and asylum seekers. Accordingly, one concrete contemporary example of the application of good faith in international law occurs in relation to the legal regime of refugees and asylum seekers.

The reason behind the existence of the good faith obligation in refugee law is historical. Being a private law principle coming from the cosmopolitan law tradition, the principle of good faith is fully equipped to be applicable to the relationships between states and other actors. In addition, as a natural law principle, it is the main criterion in interpreation of international treaties according to natural equity. The principle of good faith protects its historical importance, requiring every case to be treated in its own merit and balancing different interests in international arena. Good faith, being the ethical basis of international law is one of the life jackets we can use, when sailing the legal world.

\section{BIBLIOGRAPHY}

Burdese, Alberto. Manuale di Diritto Privato Romano, Torino: UTET, 1969.

CAvallar, George. « Jean Jacques Rousseau » in The Oxford Handbook of the History of International Law, ed. Barno Fassbender and Anne Peters, Oxford: Oxford University Press, 2012: 1114-1117. 
Cohn, Haim. « The Grotian Concept of Good Faith », Tel Aviv University Studies in Law 7 (1985-1986): 9-19.

Domat, Jean. Les Loix Civiles dans Leurs Ordre Naturel, Paris: 1703.

FASSBENDER, Barno. « Hans Kelsen » in The Oxford Handbook of the History of International Law, ed. Barno Fassbender and Anne Peters, Oxford: Oxford University Press, 2012: 1167-1172.

Freyburger, Gérard. Fides, Étude Sémantique et Religieuse Depuis les Origines jusqu'à l'Époque Augustéenne, Paris: Les Belles Lettres, Collection d'Études Anciennes. Antiquité Latine, No: 35, 1986.

Gallo, Filippo. « Bona Fides E Ius Gentium », in Il Ruolo della Buona Fede Oggettiva nell'Esperienza Giuridica Storica e Contemporanea atti del Convegno Internazionale di Studi in Onore di Alberto Burdese, ed. Alberto Burdese, Luigi Garofalo, Padova: CEDAM, 2003: 115-153.

Goodwin-Gill, Guy. « Article 31 of the 1951 Convention relating to the Status of Refugees: Non-penalization, Detention and Protection »UNHCR Department of International Protection Papers, 2011.

Goodwin-GiLl, Guy. « Damian v. Secretary of State for the Home Department Comment: Refugee Status and Good Faith » International Journal of Refugee Law 12, n. ${ }^{\circ}$ 4, 2000: 663-671.

Goodwin-Gill, Guy. « The International Law of Refugee Protection » in The Oxford Handbook of Refugee and Forced Migration Studies, ed. Elena Fiddian-Qasmiyeh, Gil Loescher, Katy Long, Nando Sigona, Oxford: Oxford University Press, 2014: 36-48.

Gordley, james Gordley, « Good Faith in Contract Law in Medieval Ius Commune " in Good Faith in European Contract Law, ed. Simon Whittaker and Reinhard Zimmermann, Cambridge: Cambridge University Press, 2000: 93-118.

HaAkonssen, Knud. « Samuel Pufendorf » in The Oxford Handbook of the History of International Law, ed. Barno Fassbender and Anne Peters, Oxford: Oxford University Press, 2012: 1102-1105.

Hausmaninger, Herbert et al., Römisches Privatrecht, Wien: Böhlau, 9. Auflage, 2001.

HÜRLIMANN-KauP, Bettina et al., Einleitungsartikel des ZGB und Personenrecht, Basel: Schultess, 2. Auflage, 2010.

JouAnnet, Emanuelle. « Emer de Vattel» in The Oxford Handbook of the History of International Law, ed. Barno Fassbender and Anne Peters, Oxford: Oxford University Press, 2012: 1118-1121.

Jörs, Paul et al., Römisches Recht, Heidelberg: Springer, 3. Auflage, 1949.

KASER, Max et al., Römisches Privatrecht, München: C. H. Beck, 21. Auflage, 2019.

Koskenniemi, Martti. « History of International Law Histories » in The Oxford Handbook of the History of International Law, ed. Barno Fassbender and Anne Peters, Oxford: Oxford University Press, 2012: 943-971.

LorCA, Arnulf Becker. « Eurocentrism in the History of International Law » in The Oxford Handbook of the History of International Law, ed. Barno Fassbender and Anne Peters, Oxford: Oxford University Press, 2012: 1034-1057.

Mommsen, Theodor. Römische Geschichte, 1. Band, (Berlin: Weidmannsche, 2. Auflage, 1856. 
Nussbaum, Arthur. « The Significance of Roman Law in the History of International Law », University of Pennsylvania Law Review 100, n. ${ }^{\circ}$ 105, 1952: 678-687.

Piotrowicz, Ryszard. " Asylum Seekers, Good Faith and the State » International Joumal on Minority and Group Rights 20, 2013: 263-278.

Pugliese, Giovanni. Istituzioni Di Diritto Romano, Torino: Giappichelli, 2. Edizione, 1992.

Robaye, René. Le Droit Romain, Louvain-la-Neuve: Academia-Bruylant, 5. Édition, 2016.

Scattola, Merio. " Alberico Gentili » in The Oxford Handbook of the History of International Law, ed. Barno Fassbender and Anne Peters, Oxford: Oxford University Press, 2012: 1092-1097.

Simons, Walter. The Evolution of International Public Law in Europe Since Grotius, New Haven: Yale University Press, 1931.

Tuck, Richard. The Rights of War and Peace, New York: Oxford University Press, 1999.

TUORI, Kaius. « The Reception of Ancient Legal Thought in Early Modern International Law Histories» in The Oxford Handbook of the History of International Law, ed. Barno Fassbender and Anne Peters, Oxford: Oxford University Press, 2012: 1012-1033.

UÇARYILMAZ, Talya. Bona Fides, Ankara: Yetkin Yayınevi, 2018.

VILley, Michel, Le Droit Romain, Paris: Puf, 2012.

VIRALly, Michel. « Good Faith in Public International Law » The American Journal of International Law, 77, n. ${ }^{\circ}$ 1, 1983: 130-134.

WhitTAKer, Simon and ZimmermanN, Reinhard. « Good Faith in European Contract Law: Surveying the Legal Landscape » in Good Faith in European Contract Law, ed. Simon Whittaker and Reinhard Zimmermann, Cambridge: Cambridge University Press, 2000: 7-63.

Wolf, Manfred et al., Allgemeiner Teil des Bürgerlichen Rechts, München: C.H. Beck, 10. Auflage, 2012. 


\title{
THE PRINCIPLE OF GOOD FAITH IN PUBLIC INTERNATIONAL LAW
}

\author{
El principio de buena fe en el Derecho internacional público
}

\author{
Talya Uçaryılmaz \\ Oxford Institute of European and Comparative Law \\ Bilkent University Faculty of Law \\ http://dx.doi.org/10.18543/ed-68(1)-2020pp43-59
}

\section{Copyright}

Estudios de Deusto es una revista de acceso abierto, lo que significa que es de libre acceso en su integridad. Se permite su lectura, la búsqueda, descarga, distribución y reutilización legal en cualquier tipo de soporte sólo para fines no comerciales, sin la previa autorización del editor o el autor, siempre que la obra original sea debidamente citada y cualquier cambio en el original esté claramente indicado

Estudios de Deusto is an Open Access journal which means that it is free for full access, reading, search, download, distribution, and lawful reuse in any medium only for non-commercial purposes, without prior permission from the Publisher or the author; provided the original work is properly cited and any changes to the original are clearly indicated. 